\title{
An overview of a regional meteorology warning system
}

\author{
S. Gaztelumendi ${ }^{1,2}$, J. Egaña ${ }^{1,2}$, K. Otxoa-de-Alda ${ }^{1,2}$, R. Hernandez ${ }^{1,2}$, J. Aranda ${ }^{3}$, and P. Anitua ${ }^{3}$ \\ ${ }^{1}$ Basque Meteorology Agency (Euskalmet), Vitoria-Gasteiz, Spain \\ ${ }^{2}$ TECNALIA, Meteo Unit, Vitoria-Gasteiz, Spain \\ ${ }^{3}$ Basque Government, Interior Dept., Directorate of Emergencies and Meteorology, Vitoria-Gasteiz, Spain
}

Correspondence to: S. Gaztelumendi (santiago.gaztelumendi@ tecnalia.com)

Received: 15 January 2012 - Revised: 23 May 2012 - Accepted: 5 June 2012 - Published: 9 August 2012

\begin{abstract}
In this work we present a regional meteorology warning system, particularly the operational weather warning system used by the Basque Meteorology Agency (Euskalmet) for Basque Country. System considers different meteorological phenomena capable of generate warnings, and is based on combined thresholds criteria depending on particular weather event and area of territory where is applied. In this work we describe the most significant aspects related with the warning event definition and the warning bulletin. Conclusions from comparison with the former system (prior to 2009) and feedback from different users are presented.
\end{abstract}

\section{Introduction}

The Basque Meteorology Agency (Euskalmet) has among its responsibilities severe weather warning issues for the Basque Country area (see Fig. 1). This information is the basis that Basque Government Civil Protection authorities use for action, including recommendations in alert situations to the Basque population. In the beginning of operations (2003), the Euskalmet weather warning system began, as in other meteorological services in the past century (WMO, 1999), like a simple system for a reduced set of meteorological hazards based on a unique threshold criteria (GV, 2004). In the last years, the system has progressively migrated towards a more sophisticated one based on extended meteorological phenomena and a traffic-light colour concept extensively used today by other European meteorological services (WMO, 2010; GV, 2009a).

As is well known from the risk assessment community, developing an effective public warning system is a complex process that requires the integration and management of many different elements. Aspects related with data collection and analysis, decision process, issue format, content, dissemination, public reception, validation and action are crucial. There is a common agreement that a capital factor for success is fluent communication and discussion with civil protection authorities (WMO, 2006; PPW, 2002, 2004).
In order to put into perspective the early severe weather warning system evolution in the case of Basque Country, it is important to consider the Euskalmet history in the Basque Government context. In 2002, the Meteorology and Climatology Directorate (Department of Transportation and Public Work) was founded, assuming regional subjects related to meteorology and climatology. In this context was born Euskalmet. Since its creation in late 2003, it is in charge of different forecast and surveillance operational aspects, including severe weather. In late 2009, the Directorate of Emergencies and Civil Protection merged with the Directorate of Meteorology and Climatology, becoming the Directorate of Emergencies and Meteorology (DEM) in the Interior Department.

In this context, meteorology, climatology, emergencies and civil protection regional and local experts work together with other agents (health, road, infrastructures, municipalities, etc.) in order to design a new severe weather surveillance and prediction protocol (GV, 2010). During past years there were multiple meetings at different levels with different partners to design and implement early warning systems, surveillance and prediction mechanisms, intervention plans and crisis management tools.

In this work we focus only on those aspects related with the meteorological warning event definition (Sect. 2) and warning bulletin aspects (Sect. 3). Finally, some results and 


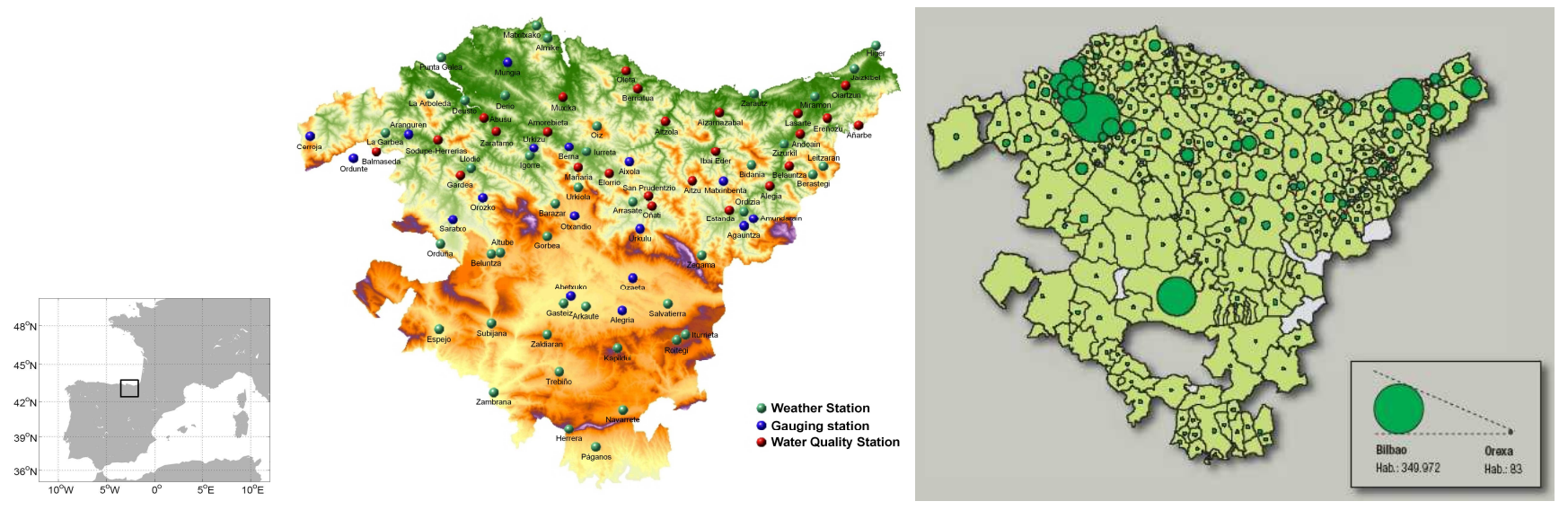

Figure 1. Basque Country Automatic Weather Station Network and population distribution.

conclusions from those years of development and operation are presented.

\section{Warning event definition}

Criteria and methodologies for defining meteorological warning events and assessing thresholds show a wide variation from one region to another (even in Europe), usually for reasons of climatology, vulnerability and operational aspects. Nevertheless, it is clear that selected thresholds must have an objective and local character, considering statistical studies for representative data in conjunction with risk analysis in a regional/local context. In Europe, the meteoalarm framework uses an extended four level colour code. Awareness colours are assigned according to impact and damage, so certain awareness levels for given phenomena have similar meaning to the public (WMO, 1999, 2002, 2003, 2005, 2010).

In the Euskalmet case, a meteorological warning event is established according to a set of thresholds for different meteorological variables or weather conditions related to potential risk situations caused by rain, snow, wind, temperatures and maritime conditions. Potential risk is evaluated based on previous experience and geographical and climatic characteristics of the area, as well as the distribution of population, properties and infrastructures in the territory (see Fig. 1).

The Basque Country Automatic Station Network (Gaztelumendi et al., 2003) is the main data source used to set up some statistical criteria such as return periods or percentiles. Even so, in the end, operational thresholds are somehow flexible and include practical experiences from historical severe weather events and considerations from the operational prediction capabilities (GV, 2010). During the weather warning process, Euskalmet experts work in cooperation with emergency experts and others agents, depending on the severity of the weather event, similar to regional health authorities during extreme temperature- related events, responsible harbour and beach authorities in coastal-maritime cases, or roads and municipality authorities responsible in snow cases.

For every warning event case, a colour coded approach scheme philosophy is assumed, considering different aspects like weather severity, weather awareness, risk level, damages and frequency of a given phenomenon in the area of Basque Country (see Table 1). In this context we consider not only all kinds of atmospheric events capable of causing damages to people or properties (red/orange level i.e. alert level), but also those susceptible to affecting in some degree a particular human activity in a given scenario (yellow level, i.e. warning level).

\subsection{Rain}

In the rain case, two different aspects are considered: intensity and persistence. As in other meteorological services, these two aspects are considered through hourly rain intensities (e.g. Spanish AEMET case) and daily rain accumulation (e.g. Meteofrance case) (see WMO, 1999, 2003; INM, 2007, Stepek et al., 2010a). In the case of local intense rainfall events, problems in Basque Country are mainly related with flash floods of minor rivers, water accumulation on roads and terrain shifts. In persistent rainfall cases, risk comes usually from flood episodes of major rivers. In order to establish the different thresholds, previous studies and expertise from meteorology, emergencies, civil protection and regional river/water authorities are considered (e.g. GV, 1997, 1999a, b, 2004; DFG, 2006; Euskalmet, 2010; Egaña et al., 2005, 2007, 2008a, 2009a; Gaztelumendi et al., 2009a).

At present, for rain warning event definition, we consider hourly precipitation of $15 / 30 / 60 \mathrm{~mm}$ (limit for strong/very strong/torrential definition) and daily precipitation of $60 / 80 / 120 \mathrm{~mm}$ for yellow/orange/red level, respectively. Those thresholds are based on a return period estimation of $1 / 2 / 5 \mathrm{yr}$ in each case, and are the same for all parts in the territory (see Table 2). Moreover, they are not far from 
Table 1. Scenario thresholds and operative procedures for severe weather events.

\begin{tabular}{|c|c|c|c|c|c|}
\hline Level & Weather & Weather Awareness & Risk & Damages & Frequency \\
\hline Green & Not dangerous & $\begin{array}{l}\text { No particular aware- } \\
\text { ness is required. }\end{array}$ & No risk. & No damages. & Usually \\
\hline Yellow & $\begin{array}{l}\text { Potentially } \\
\text { dangerous }\end{array}$ & $\begin{array}{l}\text { Keep informed espe- } \\
\text { cially depending on } \\
\text { your activity. }\end{array}$ & $\begin{array}{l}\text { No risk for general } \\
\text { population but do not } \\
\text { take any avoidable } \\
\text { risk, depending on } \\
\text { your activity. }\end{array}$ & $\begin{array}{l}\text { Some disturbances and } \\
\text { very few/occasional } \\
\text { damages. }\end{array}$ & $\begin{array}{l}\text { Many times a year/ } \\
\text { not unusual }\end{array}$ \\
\hline Orange & Dangerous & $\begin{array}{l}\text { Be very vigilant } \\
\text { and keep regularly in- } \\
\text { formed about the de- } \\
\text { tailed expected mete- } \\
\text { orological conditions. }\end{array}$ & $\begin{array}{l}\text { Moderate/high risk. } \\
\text { Follow any advice } \\
\text { given by authorities. } \\
\text { Be aware of the } \\
\text { risks that might be } \\
\text { unavoidable. }\end{array}$ & $\begin{array}{l}\text { Moderate and/or local- } \\
\text { ized damages. }\end{array}$ & Very few times a year \\
\hline Red & Very dangerous & $\begin{array}{l}\text { Keep frequently in- } \\
\text { formed about detailed } \\
\text { expected meteorolog- } \\
\text { ical conditions and } \\
\text { risks. }\end{array}$ & $\begin{array}{l}\text { Very high risk. Fol- } \\
\text { low orders and any } \\
\text { advice given by au- } \\
\text { thorities under all cir- } \\
\text { cumstances. Be pre- } \\
\text { pared for extraordi- } \\
\text { nary measures. }\end{array}$ & $\begin{array}{l}\text { Major and/or generalized } \\
\text { damages; casualties are } \\
\text { possible. }\end{array}$ & $\begin{array}{l}\text { One time in a few } \\
\text { years. }\end{array}$ \\
\hline
\end{tabular}

common thresholds used in other countries (e.g. Stepek et al., 2010a; INM, 2007). The former system considered a unique threshold of $30 \mathrm{~mm}$ in one hour, and $60 \mathrm{~mm}$ in one day (see Table 3).

\subsection{Snow}

In the snowfall case, we consider an event when meteorological conditions support snow presence during some time (hours) at surface (WMO, 1999). We establish different criteria for different areas in the territory considering population, roads/highways and infrastructures distributions together with some social aspects (see Fig. 1). In our territory, main problems linked with snow episodes are related with transportation, usually from roads/highways users. In order to define procedures and thresholds, previous studies and knowledge in snow episodes from meteorology, civil protection, emergencies, roads maintenance and municipalities experts are considered (Euskalmet, 2009a, 2010; GV, 1997, 2004, 2009a).

In the snow warning case, we divide the territory into four different areas considering altitude. First zone, between 0 and $300 \mathrm{~m}$, covers high-density populated areas in the north part of Basque Country (including Bilbao and Donostia). Second zone (300-700 m) covers the internal basin, Vitoria (Basque capital) area and main communications roads between Alava and the rest of the territory. The third zone (700-1000 m) covers less populated high land areas. No warning events are considered when snow level is over $1000 \mathrm{~m}$, as no populated areas and no main roads are present (see Fig. 2).

Yellow/orange/red levels are established for different snow accumulation depending on the area considered, as it is shown in Table 2. Note that for $0-300 \mathrm{~m}$ area (more than $77 \%$ Basque population, including Bilbao and Donostia), yellow warning level is activated just for snow presence under $1 \mathrm{~cm}$ (see Table 2). The former system considered a warning event when snow was present below $1000 \mathrm{~m}$ (see Table 3 ).

\subsection{Wind}

In the wind case, usually mean wind and/or wind gusts are used in order to characterize a windy meteorological scenario (e.g. WMO, 1999). In our case, we adopt wind gust as the key variable, which proves to be a simple and effective way to take into account problems associated with high wind, as most part of damages are produced by the short duration pushing of wind. Nevertheless, as usual in complex topography, differences are present between mountainous, coastal and inland areas (Stepek et al., 2010b).

In Basque Country cases, main damages in windy scenarios are related with fallen trees, roofs, power cuts, transportation or wildfires. Available studies and expertise from meteorology, emergencies, civil protection and local/regional authorities are considered in order to establish the reference thresholds with a scientific and practical orientation (e.g. 
Table 2. Event threshold classification using traffic-lights colour concept for new Euskalmet warning system.

\begin{tabular}{|c|c|c|c|c|c|c|c|c|}
\hline Warning Event & What? & When? & Where? & $\begin{array}{l}\text { Green } \\
\text { Level }\end{array}$ & $\begin{array}{l}\text { Yellow } \\
\text { Level }\end{array}$ & $\begin{array}{l}\text { Orange } \\
\text { Level }\end{array}$ & $\begin{array}{l}\text { Red } \\
\text { Level }\end{array}$ & Units \\
\hline $\begin{array}{l}\text { Persistent precipitation } \\
\text { risk. }\end{array}$ & Precipitation & $\begin{array}{l}\text { Accumulated } \\
\text { rain in } 24 \mathrm{~h}\end{array}$ & All the territory & $<60$ & {$[60-80)$} & {$[80-120)$} & $\geq 120$ & $1 \mathrm{~m}^{-2}$ \\
\hline $\begin{array}{l}\text { Intense precipitation } \\
\text { risk. }\end{array}$ & & $\begin{array}{l}\text { Accumulated } \\
\text { rain in } 1 \mathrm{~h}\end{array}$ & All the territory & $<15$ & {$[15-30)$} & {$[30-60)$} & $\geq 60$ & $1 \mathrm{~m}^{-2}$ \\
\hline \multirow[t]{3}{*}{ Snow risk } & & $\begin{array}{l}\text { Snow presence } \\
\text { at surface }\end{array}$ & $\begin{array}{l}\text { Altitudes } \\
0-300 \mathrm{~m}\end{array}$ & no snow & $(0-1)$ & {$[1-5)$} & $\geq 5$ & $1 \mathrm{~m}^{-2}$ or $\mathrm{cm}$ \\
\hline & & & $\begin{array}{l}\text { Altitudes } \\
300-700 \mathrm{~m}\end{array}$ & $<1$ & {$[1-5)$} & {$[5-20)$} & $\geq 20$ & $1 \mathrm{~m}^{-2}$ or $\mathrm{cm}$ \\
\hline & & & $\begin{array}{l}\text { Altitudes } \\
700-1000 \mathrm{~m}\end{array}$ & $<1$ & {$[1-10)$} & {$[10-30)$} & $\geq 30$ & $1 \mathrm{~m}^{-2}$ or $\mathrm{cm}$ \\
\hline \multirow[t]{2}{*}{ Wind risk } & Wind & $\begin{array}{l}\text { Maximum } \\
\text { Wind gust }\end{array}$ & $\begin{array}{l}\text { At exposed } \\
\text { zones }\end{array}$ & $<100$ & {$[100-120)$} & {$[120-140)$} & $\geq 140$ & $\mathrm{Km} \mathrm{h}^{-1}$ \\
\hline & & & $\begin{array}{l}\text { At non-exposed } \\
\text { zones }\end{array}$ & $<80$ & {$[80-100)$} & {$[100-120)$} & $\geq 140$ & $\mathrm{Km} \mathrm{h}^{-1}$ \\
\hline \multirow[t]{4}{*}{$\begin{array}{l}\text { Extreme low tempera- } \\
\text { tures/ice presence risk }\end{array}$} & Temperature & $\begin{array}{l}\text { Minimum } \\
\text { Temperatures }\end{array}$ & Zone 1 & $>0$ & $\leq 0$ & $\leq-2$ & $\leq-4$ & ${ }^{\circ} \mathrm{C}$ \\
\hline & & & Zone 2 & $>0$ & $\leq 0$ & $\leq-4$ & $\leq-7$ & ${ }^{\circ} \mathrm{C}$ \\
\hline & & & Zone 3 & $>0$ & $\leq 0$ & $\leq-6$ & $\leq-10$ & ${ }^{\circ} \mathrm{C}$ \\
\hline & & & Zone 4 & $>0$ & $\leq 0$ & $\leq-5$ & $\leq-8$ & ${ }^{\circ} \mathrm{C}$ \\
\hline \multirow[t]{4}{*}{$\begin{array}{l}\text { Extreme high } \\
\text { temperatures risk }\end{array}$} & & $\begin{array}{l}\text { Maximum } \\
\text { Temperatures }\end{array}$ & Zone 1 & $>3$ & $\leq 33$ & $\leq 35$ & $\leq 37$ & ${ }^{\circ} \mathrm{C}$ \\
\hline & & & Zone 2 & $>36$ & $\leq 36$ & $\leq 38$ & $\leq 40$ & ${ }^{\circ} \mathrm{C}$ \\
\hline & & & Zone 3 & $>35$ & $\leq 35$ & $\leq 37$ & $\leq 39$ & ${ }^{\circ} \mathrm{C}$ \\
\hline & & & Zone 4 & $>36$ & $\leq 36$ & $\leq 38$ & $\leq 40$ & ${ }^{\circ} \mathrm{C}$ \\
\hline \multirow[t]{4}{*}{$\begin{array}{l}\text { Persistent high } \\
\text { temperatures risk }\end{array}$} & & $\begin{array}{l}\text { Max/Min } \\
\text { Temperatures }\end{array}$ & Zone 1 & $<30 / 19$ & $\begin{array}{l}30 / 9 \text { during } \\
1-2 \text { days }\end{array}$ & $\begin{array}{l}\text { 30/19 during } \\
3-4 \text { days }\end{array}$ & $\begin{array}{l}30 / 19 \text { during } \\
\geq 5 \text { days }\end{array}$ & ${ }^{\circ} \mathrm{C}$ \\
\hline & & & Zone 2 & $<35 / 17$ & $\begin{array}{l}35 / 17 \text { during } \\
1-2 \text { days }\end{array}$ & $\begin{array}{l}35 / 17 \text { during } \\
3-4 \text { days }\end{array}$ & $\begin{array}{l}35 / 17 \text { during } \\
\geq 5 \text { days }\end{array}$ & ${ }^{\circ} \mathrm{C}$ \\
\hline & & & Zone 3 & $<35 / 17$ & $\begin{array}{l}35 / 17 \text { during } \\
1-2 \text { days }\end{array}$ & $\begin{array}{l}35 / 17 \text { during } \\
3-4 \text { days }\end{array}$ & $\begin{array}{l}35 / 17 \text { during } \\
\geq 5 \text { days }\end{array}$ & ${ }^{\circ} \mathrm{C}$ \\
\hline & & & Zone 4 & $<36 / 18$ & $\begin{array}{l}36 / 18 \text { during } \\
1-2 \text { days }\end{array}$ & $\begin{array}{l}36 / 18 \text { during } \\
3-4 \text { days }\end{array}$ & $\begin{array}{l}36 / 18 \text { during } \\
\geq 5 \text { days }\end{array}$ & ${ }^{\circ} \mathrm{C}$ \\
\hline \multirow[t]{3}{*}{ Coastal-maritime risk } & $\begin{array}{l}\text { Waves/maritime } \\
\text { conditions }\end{array}$ & $\begin{array}{l}\text { Significant high } \\
\text { wave in summer }\end{array}$ & $0-2$ miles & $<2$ & {$[2-3.5)$} & {$[3.5-5.5)$} & $\geq 5.5$ & $\mathrm{~m}$ \\
\hline & & $\begin{array}{l}\text { Significant high } \\
\text { wave (winter, } \\
\text { autumn, spring) }\end{array}$ & $0-2$ miles & $<3.5$ & {$[3.5-5)$} & {$[5-7)$} & $\geq 7$ & $\mathrm{~m}$ \\
\hline & $\begin{array}{l}\text { Coastal Trapped Dis- } \\
\text { turbance (CTD) phe- } \\
\text { nomena or similar }\end{array}$ & $\begin{array}{l}\text { Rapid change in } \\
\text { Wind direction } \\
\text { and module } \\
\text { intensification } \\
\text { (wind gust) }\end{array}$ & $\begin{array}{l}\text { Coastal area } \\
\text { (Zone } 1 \text { plus } 2 \\
\text { miles offshore) }\end{array}$ & $<60$ & {$[60-90)$} & {$[90-120)$} & $\geq 120$ & $\mathrm{Km} \mathrm{h}^{-1}$ \\
\hline
\end{tabular}

Euskalmet, 2010; GV, 2004; Egaña et al., 2004; Egaña and Gaztelumendi, 2009; Gaztelumendi et al., 2009b).

In the wind case, we consider a territory distribution on exposed and non-exposed zones due to historical wind data series, topography and population/infrastructures allocation. Exposed zones are mountainous, and shoreline zones and non-exposed areas correspond to the rest of the territory (see Fig. 2). We consider wind gust limits of $80 / 100 / 120 \mathrm{~km} \mathrm{~h}^{-1}$ and $100 / 120 / 140 \mathrm{~km} \mathrm{~h}^{-1}$ for yellow/orange/red level for exposed and non-exposed zones, respectively (see Table 2). Those values are established for return periods of less than one year in the yellow case and one-three years in orange/red case, not far from values used by other services in Europe and particularly for those used by French and Spanish Met services (Stepek, 2010b; INM, 2007). The former system is based on a unique gust threshold of $80 / 100 \mathrm{~km} \mathrm{~h}^{-1}$ for nonexposed and exposed zones (see Table 3 ).

\subsection{Temperatures}

In order to consider human response to heat and cold events, in the context of operational meteorological warning definitions, different approaches are possible based on different event definitions and temperature indexes considerations (see WMO, 1999, 2004; WHO, 2009; InVS, 2005; Robinson, 2001). In our case, we consider extreme high and low temperatures, and persistence of high temperatures (in some sense, heat-waves). This is done in order to consider major temperature-related incidences in our territory, mostly dealing with human health. In extremely high temperature cases, they are mainly due to dehydration or heatstroke usually as results from vigorous physical activity. When excessive heat persists, some chronic affections may worsen, especially in the elderly or very young populations. In the case of very cold temperatures, direct human health impacts come from 
Table 3. Event threshold classification for former Euskalmet warning system.

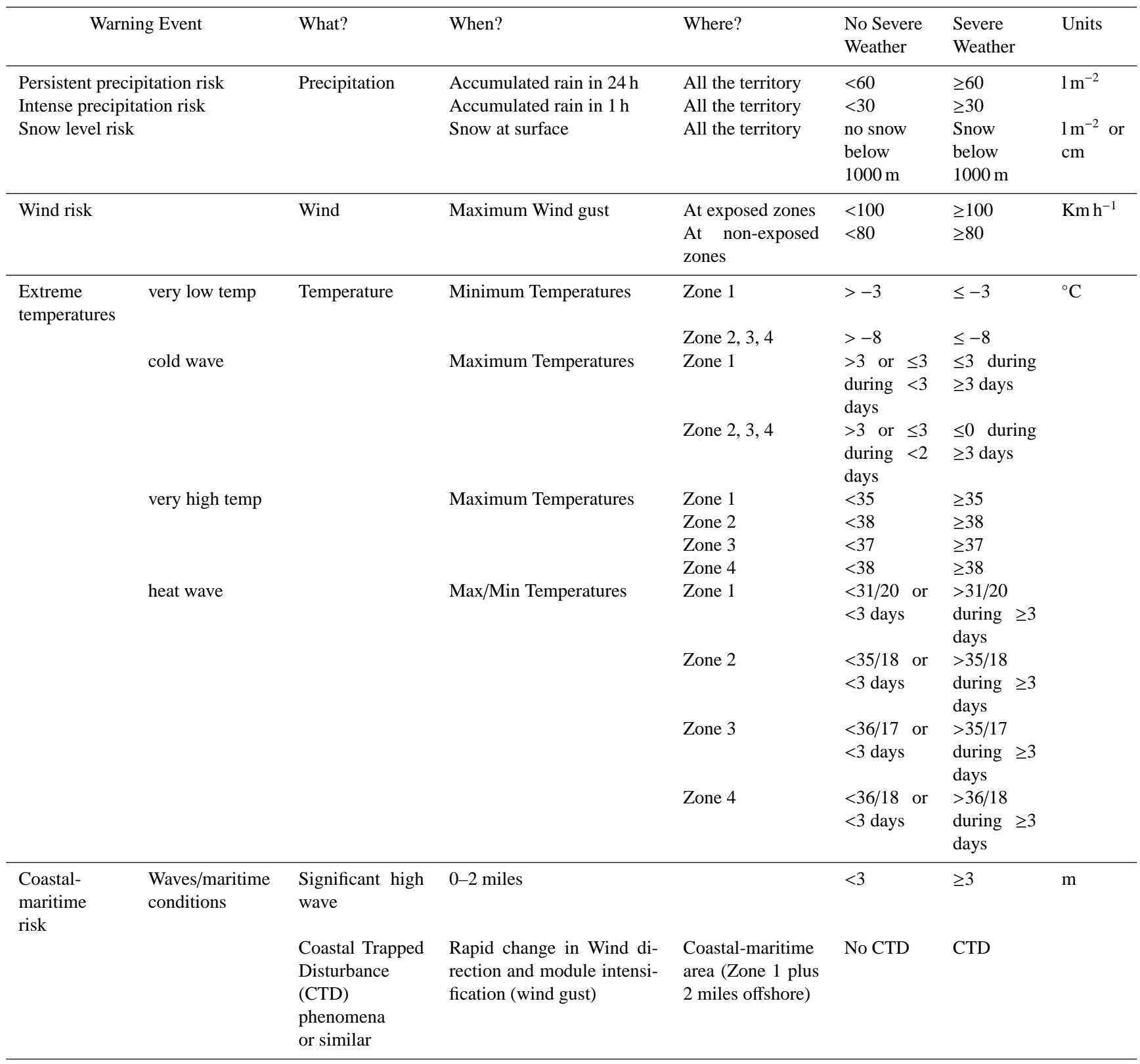

lack of awareness of hypothermia and protection against cold environmental conditions, and indirectly from car accidents due to ice on roads.

In Basque Country cases, we just use maximum and minimum temperatures as meteorological variables for severity definition. We have divided the area into four different zones according to climatology and similar meteorological behavior. These four zones correspond to the coastal area (zone 1) to the Cantabric interior zone (zone 2), the transition zone (zone 3) and the Ebro basin zone (zone 4), as can be seen in Fig. 4.
In order to establish zonification and the different reference thresholds, available studies and knowledge from meteorology, emergencies, civil protection and health authorities are considered (e.g. Euskalmet, 2005, 2010; Egaña et al., 2009b, 2010a, 2005; GV, 2009b, 2004).

In the case of extremely low temperatures, we consider yellow threshold as zero degrees in order to capture any potential problem in roads due to ice formation. For the orange/red alert level, minimum temperature thresholds are established for each zone according to percentile 1/0 for a set of representative temperature data. In the extreme high temperature event case, temperature thresholds are based on 


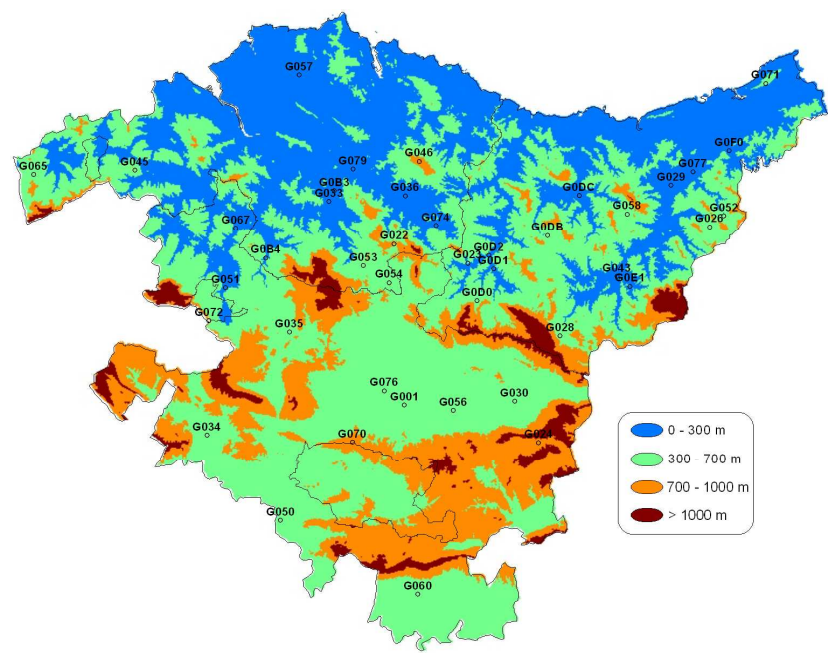

Figure 2. Snow warning areas and heated rain gauge distribution.

percentile 95/99/100 for yellow/orange/red levels, respectively, using temperature series for the same representative weather stations. Finally, in the high temperature persistence event, a combination of daily $\mathrm{max} / \mathrm{min}$ temperatures are considered taking into account the 95 percentile; yellow/orange/red level are considered when this situation remains for 1-2 days, 3-4 days or more than 5 days respectively (Table 2).

The former system assumes a heat wave episode when during three or more consecutive days we have daily temperature maximum and minimum down to 95 percentile in each of the four different zones. We define a very high temperature situation when the maximum temperatures will be superior to 99 percentile at any point of each zone. For minimum temperature cases a 1 percentile was used (Table 3 ).

\subsection{Maritime-coastal}

For a maritime-coastal warning event, we consider two aspects that usually promote problems for Basque country coastal and maritime areas under Gales, Maritime storm, rapid cyclogenesis or wind reversal ("Galerna") conditions. In order to consider in an easy and effective way these phenomena, we focus on significant wave height in coastal waters and some criteria for sudden wind shift and intensification under Galerna conditions (see Table 2).

Usually damages and personal injuries associated with wave events in Basque Country are related with small ships, beaches and coastal-promenade users. In Euskalmet cases, we assume that a good reference variable is the significant wave height considered in the near coastal zone (less than 6 miles). Thresholds for significant wave height are established according to previous experiences in historical maritime-coastal severe events, some statistical studies based on wave data available from the Basque Coast and forecast aspects (e.g. Euskalmet, 2010; GV, 2004; Egaña and Gaztelu-

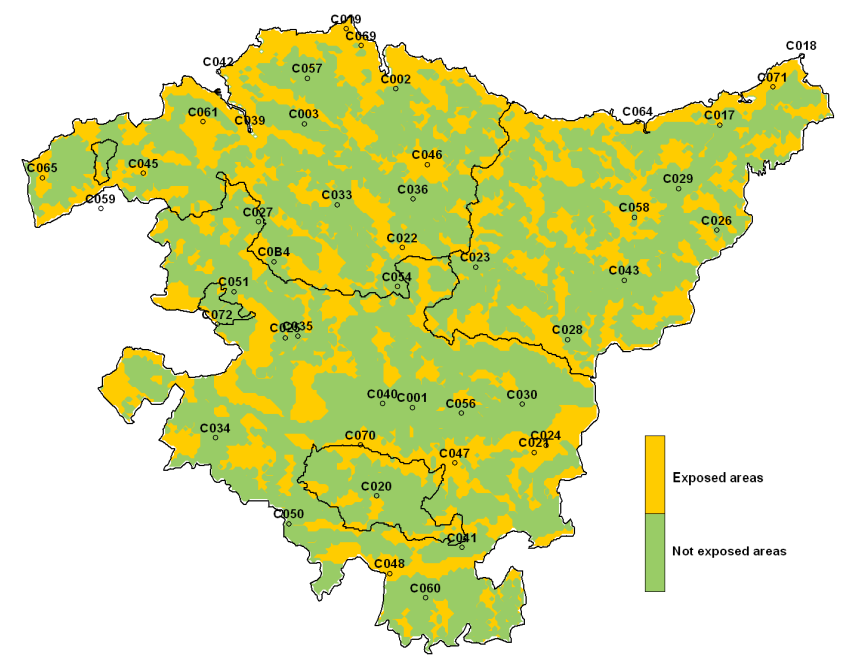

Figure 3. Wind warning areas and wind sensor distribution.

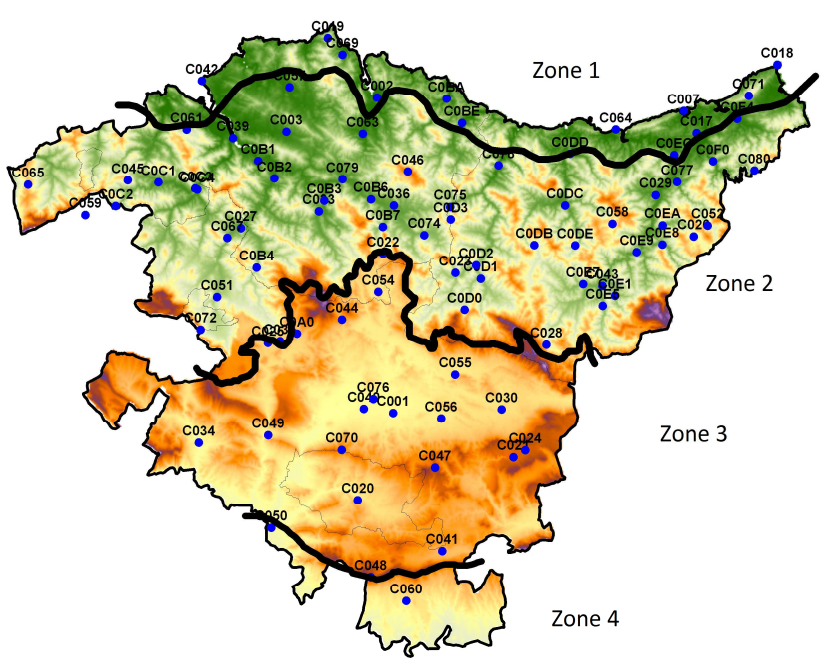

Figure 4. Temperature warnings areas and temperature sensor distribution.

mendi, 2009; Egaña et al., 2010b; Gaztelumendi et al., 2008, $2009,2010 \mathrm{a})$. Limit values of $3.5 / 5 / 7 \mathrm{~m}$ and $2 / 3.5 / 5.5 \mathrm{~m}$ for yellow/orange/red level in winter and summer time, respectively, are used (Table 2). Seasonal criteria are introduced to consider increasing risk in summer time (from beaches and marinas).

On the other hand, problems associated with a Galerna event affect beach users, fishermen and small ships users. During a Galerna episode, wind turns and intensifies suddenly from $\mathrm{S}$ to NW in few minutes, affecting a few kilometers onshore and offshore, and propagates along the coast from west to east (e.g. Euskalmet, 2010; Arasti Barca, 2001; Gaztelumendi et al., 2011). In such cases a combined criteria is used, assigning colours depending on wind gust value (see Table 2) and sea state (GV, 2010). The former system 


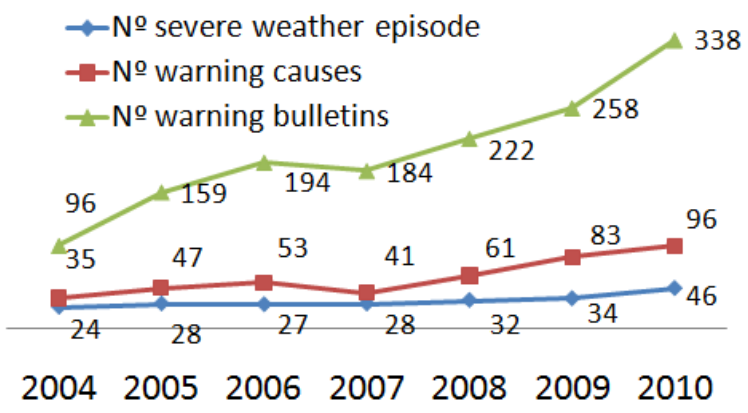

Figure 5. Number of severe weather episodes related with warning causes and number of bulletins by year, for 2004-2010 period.

considered a significant wave height threshold of $3 \mathrm{~m}$, and the Galerna yes/no occurrence (see Table 3).

\section{Warning bulletins}

Thresholds and different criteria we have described are used to distinguish different warning events in a potential severe weather scenario, and to proceed with internal Euskalmet operational routines, including the issuance of warning bulletins. In these cases, actions must be taken according to the Basque Government protocol for prediction and surveillance in severe weather cases (GV, 2010). Implemented procedures, including warnings bulletin elaboration and dissemination, respond to international findings and recommendations for early warning systems development and operations (e.g. WMO, 2002, 2010; PPW, 2002, 2004), and noteworthy are not far from practices in nearby countries such as France or Spain (see WMO, 1999, 2003; INM, 2007).

Under a potential warning event, Euskalmet operational staff (forecast team, senior forecaster and coordinator) analyze the situation (severe weather briefing) and translate recommendations for warning issuance to meteorology responsible within the DEM. When the recommendation from Euskalmet includes orange/red level, briefings and the decision chain extend to emergencies and civil protection parts within the DEM.

It is worth mentioning that a yellow warning is considered for awareness situations so remains at the information level under the meteorological part of the decision chain. Orange and red warnings are considered for alert situations and focus on threats to civil protection, as actions must be taken (see Table 1). Although the meteorological warning bulletin format essentially remains the same format, different dissemination and communication procedures are considered depending on the warning level (GV, 2011).

\subsection{Content}

Effective warning messages must be short, concise, understandable, and actionable, answering the questions of "what?", "where?", “when?", "why?", and "how to re- spond?". Usually they include a heading, a headline that summarizes the most important aspects, a descriptive text, and depending on case include non-technical information for public safety (WMO, 2002; PPW, 2002, 2004).

In our study case the warning bulletin includes a title with warning event causes. For each day, we include a sentence for each warning event with colour level, time period, affected area, and finally an explanatory and concise text describing the particular situation and probability of occurrence. The bulletin has two parts: one for forecast and one for observations. The observation part is used for relevant registered data or to incorporate warnings if a non-previously forecasted warning event is observed. We have developed different tools to help in diagnostic and prognostic procedures for warning events and severe weather scenarios identification. In the prognostic part, information coming from different available numerical models and nowcasting systems is the most important information source (e.g. Egaña et al., 2008b; Gaztelumendi et al., 2005, 2007, 2008a; Gelpi et al., 2006a, b). In the observation part, real-time information coming from the AWS mesonet and other data sources available for surveillance purposes is essential (e.g. Aranda and Morais, 2006; Gaztelumendi et al., 2003, 2005, 2006a, b, c, 2009c, 2010b; Hernández et al., 2010; Maruri et al., 2009).

Depending on the warning cause, complementary information is included with the warning bulletin. In snow cases, it consists of a special bulletin containing relevant text, extra graphical and tabular information on the event evolution, including iso0, snow level and precipitation forecast for next four days. In persistent temperature cases, a special bulletin with maximum and minimum temperature tables for each zone and for seven days ahead is incorporated (GV, 2010; Euskalmet, 2009a, b).

Warnings need to be understable, accessible, timely and tied to response actions to be taken by the people (WMO, 2002; Basher, 2006). For this purpose, for red and orange scenarios, information is specially prepared for media (radio, $\mathrm{TV}$, newspapers) focusing on what is happening or going to happen and why/what to do to minimize harm.

\subsection{Dissemination}

Effective early warnings have to be communicated and disseminated to people to ensure they are warned in advance of impending hazardous events and to facilitate civil protection and others authority activities (WMO, 2002). In Euskalmet cases a supervised system was implemented for easier elaboration of different warning products. Operational personnel must fill out different input forms for the available software. The system formats this information for its dissemination, including e-mail and the web. All the products are elaborated in Spanish and Basque languages.

In Basque Country, case warning information (via mail and web) are routinely updated at 10:30 and 19:30 LT. If new relevant information is available, the update is done at the 


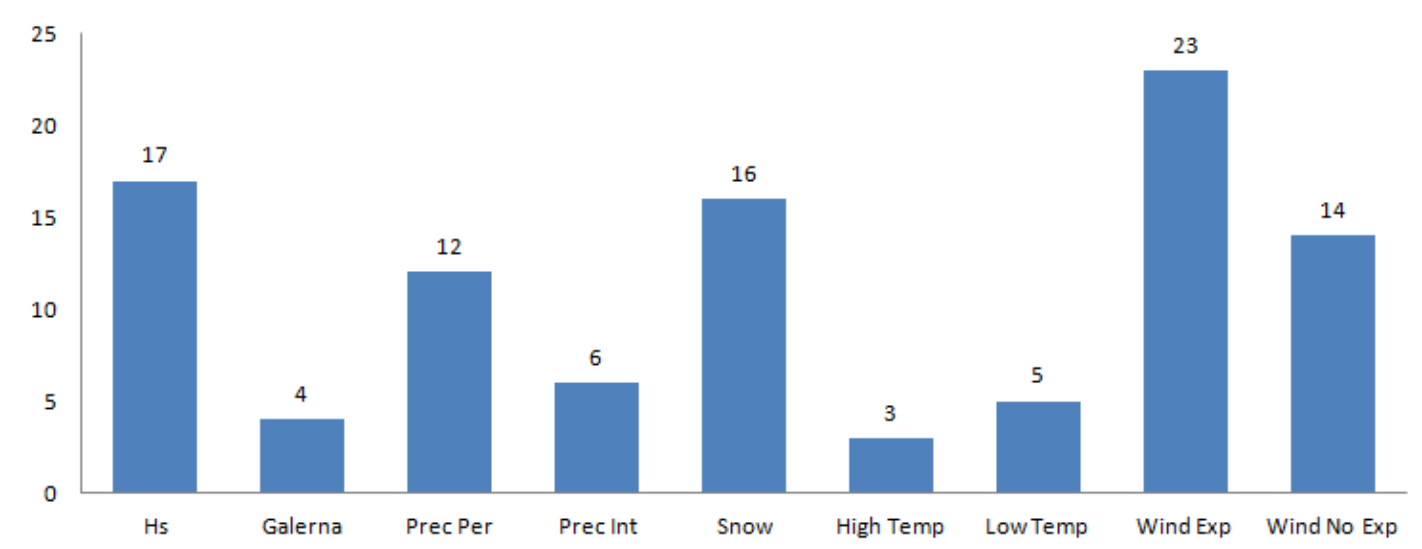

Figure 6. Warning causes frequency (\%), for 2004-2010 period.

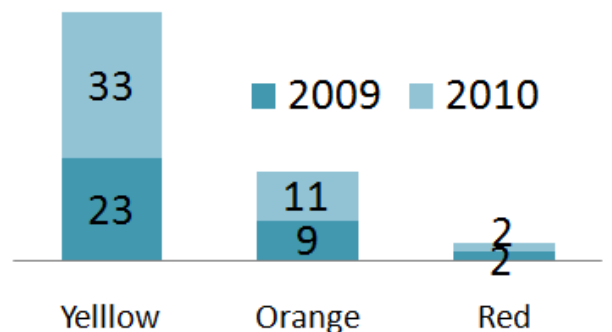

Figure 7. Number of worst warning level colour reached in 2009 and 2010 severe weather episodes.

time it becomes available. Warning information is disseminated to the public $24 / 48 \mathrm{~h}$ previous to the occurrence. The first Euskalmet warning bulletin was issued in May 2004; the first warning bulletin based on traffic light concept was issued in January 2009. In 2011 we started to include Twitter in the warning dissemination procedures.

To be effective, warnings must have not only a scientific/technical basis but also a strong focus on the people exposed to risk (WMO, 2010). Different zonification based on meteorological criteria are translated to political entities (provincial and municipalities) as is needed for civil protection actions and efficient dissemination. Particular communications actions are planned, depending on the warning event, in order to disseminate information effectively to those agents potentially affected or involved in security aspects at the local level (GV, 2010).

\section{Results}

From 2004 to 2010, 219 weather warning episodes were produced, with a mean ratio of 30 per year. During the same period, 1491 bulletins were issued, for an average rate of more than 200 per year. From the cause perspective, $23 \%$ cases dealt with wind in exposed zones, $17 \%$ with high waves and $16 \%$ with snow events (see Figs. 5 and 6 ).
The new traffic light-based warning system proves to be an easy way for rapid identification of risk, removing in part difficulties for the general population in understanding meteorological language. Colour levels are an intuitive way to transmit risk and to prepare the population for a proactive response to recommendations, even for extraordinary measures required when a red level is activated, as in the case of the Klaus event (Gaztelumendi et al., 2009b).

In the Basque Country case, warning issues are never activated automatically and never based on a single-man philosophy; the decision chain must be followed and a consensus with emergency part is always needed. In the end, surpassing established meteorological thresholds is important but, in the operational perspective, are just used as guidelines. For instance, yellow level for temperatures below zero degrees is established depending on ice formation probability, or in wave cases some considerations to tides or wave periods are taken into account. Experience during those years of operation showed that a more open and complete vision is needed, especially in red level cases where human losses are feasible.

This new philosophy has had an impact on the increase of warning events during those last years (see Fig. 5), mainly due to new yellow thresholds affecting temperature, precipitation and wave events.

The rise in the number of warning bulletins observed (Fig. 5) is a direct consequence of the increase in warning events (severe weather events), but also reflects a tendency for issuing warning bulletins more than two days in advance. In pre-2009 situations, the number of bulletins issued per warning event was around 6.5, whereas in the new scenario it has increased to 7.5 .

During 2009 and 2010, the number of red/orange events stays around 2/10 events per year, whereas in the yellow cases an increase from 23 in 2009 to 33 in 2010 is observed, mainly due to an increase in extreme temperatures and wave related events during 2010 (Fig. 7). 


\section{Conclusions}

In this work we present an overview of a regional meteorology warning system focusing on main aspects related with warning event definition and warning bulletin generation and dissemination, putting this system into perspective with the former system available in Basque Country before 2009, as well as other international practices.

Both meteorology and emergency experts are essential in the formulation of severe weather risk decisions. The first are experts in assigning probability of occurrence of a weather related hazard, and the second are experts in the vulnerability evaluation to a particular hazard. This duality is a key component, not only in the thresholds/criteria for warning event definition, but also at the time of warning issues and dissemination. The new Basque Government context (meteorology and civil protection partners under the same structure) promotes synergies to ensure that users get full benefit of reliable forecasts and warnings.

From an operational meteorological point of view, some problems still remain in the new system. The temperature thresholds used are near expected prognosis error. The new yellow level for minimum temperature is often activated during long winter periods in some areas. Snow events according to established criteria are very difficult to predict and to validate.

In the future, new concepts will be introduced in the system, like taking into account storms in a clearer way, improving dissemination; or considering radar capabilities for rain episodes under $1 \mathrm{~h}$ duration, among others.

Acknowledgements. The authors would like to thank the Emergencies and Meteorology Directorate - Interior Department Basque Government for public provision of data and operational service financial support. We also would like to thank all our colleagues from Euskalmet for their daily effort in promoting valuable services for the Basque community. Finally we would like to thank to all partners that participate in the Severe Weather Surveillance and Prediction Plan elaboration for the Basque Country.

Edited by: B. Reichert

Reviewed by: two anonymous referees

\section{References}

Aranda, J. A. and Morais, A.: The new weather radar of Euskalmet. Site selection, construction and installation, Proceedings 4th ERAD Conference, 356-359, 2006.

Arasti Barca, E.: Estudio de la galerna típica del Cantábrico, INM, ISBN: 84-8320-175-5, 2001.

Basher, R.: Global early warning systems for natural hazards: systematic and people-centred, Phil. Trans. R. Soc. A, 364, 21672182, 2006.

DFG (Diputacion Foral de Gipuzkoa): Caracterización de las situaciones hidrológicas extremas en Gipuzkoa y situación frente a inundaciones en Gipuzkoa, 2006.
Egaña, J. and Gaztelumendi, S.: Klaus overview and comparison with other cases affecting Basque Country area, Proceedings of the 5thECSS Conference, 6 pp., 2009.

Egaña, J., Gaztelumendi, S., Gelpi, I. R., and Otxoa de Alda, K.: Synoptic characteristics of extreme wind events in the Basque Country, 6th EMS Conference, 2004.

Egaña, J., Gaztelumendi, S., Mugerza, I., and Gelpi, I. R.: Synoptic patterns associated to very heavy precipitation events in the Basque Country, 5th EMS Conference, 2005.

Egaña, J., Gaztelumendi, S., Gelpi, I. R., and Otxoa de Alda, K.: A preliminary analysis of summer severe storms in the Basque Country area: synoptic characteristics, 4th ECSS Conference, 2007.

Egaña, J., Gaztelumendi, S., Gelpi, I. R., Otxoa de Alda, K., Maruri, M., and Hernández, R.: Radar Analysis of Different Meteorological Situations in the Basque Country Area, Proceedings 5th ERAD Conference, Helsinki, 4 pp., 2008a.

Egaña, J., Gaztelumendi, S., Otxoa de Alda, K., Gelpi, I. R., and Hernandez, R.: Synoptical and mesoscale information for forecast purposes, 8thEMS/7thECAC Conference, 2008b.

Egaña, J., Gaztelumendi, S., Pierna, D., Gelpi, I. R., and Otxoa de Alda, K.: "Convective storms over Basque Country: June 2008 cases study", Proceeding of the 5th ECSS Conference, 291-292, 2009a.

Egaña, J., Gaztelumendi, S., Otxoa de Alda, K., and Gelpi, I. R.: Synoptic characteristics of extreme heat episodes in the Basque Country, 9th EMS/9th ECAM Conference 2009b.

Egaña, J., Gaztelumendi, S., Otxoa de Alda, K., and Gelpi, I. R.: Synoptic characteristics of extreme low temperatures episodes in the Basque Country, 10thEMS/8thECAC Conference, 2010a.

Egaña, J., Gaztelumendi, S., Gelpi, I. R., and Otxoa de Alda, K.: Analysis of oceano-meteorological conditions during Klaus episode on Basque Country area, 10thEMS/8th ECAC Conference, 2010 b.

Euskalmet: Estudio de umbrales de temperatura para la CAPV, 2005.

Euskalmet: Procedimiento operativo ante situaciones de nieve, 2009a.

Euskalmet: Procedimiento operativo ante situaciones de temperaturas altas extremas, 2009b.

Euskalmet: Compendio de informes meteorológicos anuales, 2010.

Gaztelumendi, S., Otxoa de Alda, K., and Hernandez, R.: Some aspects on the operative use of the automatic stations network of the basque country, 3th ICEAWS Conference, 2003.

Gaztelumendi, S., Egaña, J., Gelpi, I. R., and Mugerza, I.: An Automatic Warning and Alert system: Design and validation, 5th EMS Conference, 2005.

Gaztelumendi, S., Otxoa de Alda, K., Gelpi, I. R., and Egaña, J.: An Automatic Surveillance System for Severe Weather Real Time Control in Basque Country Area, 4th ICEAWS Conference, 2006a.

Gaztelumendi, S., Egaña, J., Gelpi, I. R., Otxoa de Alda, K., Maruri, M., and Hernández, R.: The new radar of Basque Meteorology Agency: Configuration and some considerations for its operative use, Proceedings 4th ERAD Conference, 363-366, $2006 \mathrm{~b}$.

Gaztelumendi, S., Otxoa de Alda, K., Egaña, J., and Gelpi, I. R.: Inclusion of Radar information in the surveillance panel of the Basque Meteorology Agency, Proceedings 4th ERAD Conference, 352-355, 2006c. 
Gaztelumendi, S., Gelpi, I. R., Egaña, J., and Otxoa de Alda, $\mathrm{K}$.: Mesoscale numerical weather prediction in Basque Country Area: present and future, EMS7/ECAM8 Conference, 2007.

Gaztelumendi, S., Egaña, J, Gelpi, I. R., and Otxoa de Alda, K.: The Euskalmet wave forecast system - preliminary results and validation, Proceedings 5th EuroGOOS Conference, 168-176, 2008a.

Gaztelumendi, S., Hernandez, R., Otxoa de Alda, K., Egaña, J., and Gelpi, I. R.: Basque Meteorology Agency annual meteorological bulletins, 8thEMS/7thECAC Conference, 2008b.

Gaztelumendi, S., Otxoa de Alda, K., Egaña, J., Gelpi, I. R., Pierna, D., and Carreño, S: Summer showers characterization in the Basque Country, Proceedings of the 5th ECSS, 81-82, 2009a.

Gaztelumendi, S. and Egaña, J.: Klaus over Basque Country: Local characteristics and Euskalmet operational aspects, Proceedings of 5th ECSS, 255-256, 2009b.

Gaztelumendi, S., Lopez, J., Egaña, J., and Aranda, J. A.: Preliminary results from lightning detection in Basque Country, 5th ECSS Conference, 2009c.

Gaztelumendi, S., González, M., Egaña, J., Rubio, A., Gelpi, I. R., Fontán, A., Otxoa de Alda, K., Ferrer, L., Alchaarani, N., Mader, J., and Uriarte, Ad.: Implementation of an operational oceanometeorological system for the Basque Country, Thalassas, 26, 151167, 2010a.

Gaztelumendi, S., Otxoa de Alda, K., Hernández, R., Egaña, J., and Gelpi, I. R.: Meteosat products for surveillance: the Euskalmet case, Proceedings 2010 EUMETSAT Conference, p. 57, 6 pp., $2010 \mathrm{~b}$.

Gaztelumendi, S., Egaña, J., Ruiz, M., Pierna, D., Otxoa de Alda, K., and Gelpi, I. R.: An analysis of Cantabric coastal trapped disturbances, 6th EuroGOOS Conference, 2011.

Gelpi, I. R., Gaztelumendi, S., Egaña, J., and Otxoa de Alda, K.: Implementing a Data Assimilation System: Preliminary Results, 6th EMS Conference, 2006a.

Gelpi, I. R., Gaztelumendi, S., Otxoa de Alda, K., and Egaña, J.: Some results from assimilation on Kapildui radar wind information in the Basque Country, Proceedings of the 4th ERAD Conference, 550-552, 2006b.

GV (Gobierno Vasco): Plan de Protección Civil de Euskadi, 1997.

GV: Plan Integral de Prevención de Inundaciones (PIPI), 1999a.

GV: Plan Especial de Emergencias ante el Riesgo de Inundaciones de la CAPV, 1999 b.

GV: Protocolo para la predicción y vigilancia de fenómenos meteorológicos adversos, 2004

GV: Plan de predicción y vigilancia de fenómenos meteorológicos adversos, Dirección de Meteorología y Climatología, 2009a.

GV: Procedimiento operativo en situaciones de temperaturas altas persistentes y temperaturas altas extremas, Dirección de Meteorología y Climatología 2009b.
GV: Protocolo para la predicción, vigilancia y actuación ante fenómenos meteorológicos adversos, Departamento de interior, 2010.

Hernández, R., Gaztelumendi, S., Otxoa de Alda, K., Gelpi, I. R., and Egaña, J.: Combining Meteosat data and weather radar products to improve the meteorological surveillance and nowcasting, Proceedings 2010 EUMETSAT Conference, p. 57, 6 pp., 2010.

INM: Plan nacional de predicción y vigilancia de meteorología adversa - meteoalerta, Ministerio de Medio Ambiente, Gobierno de España, 2007.

InVS (Institut de Vielle Sanitaire): Système d'alerte canicule et santé (SACS) Raport, June 2005.

Maruri, M., Gaztelumendi, S., Gelpi, I. R., and Egaña, J.: Some quality aspects related with Punta Galea wind profiler and Kapildui weather radar, 8th International Symposium on Tropospheric Profilling, Delft, 2009.

PPW (Partnership for Public Warning): Developing a unified allhazard public warning system, PPW-Report, 2002.

PPW: An introduction to public alert and warning, PPW-Report, 2004.

Robinson, P. J.: On the definition of heat waves, J. Appl. Meteorol., 40, 762-765, 2001

Stepek, A., Wijnant, I. L., and van der Schrier, G.: Analysis of daily precipitation thresholds in Meteoalarm, ECA\&D Report, 2010a.

Stepek, A., Wijnant, I. L., and van der Schrier, G.: Analysis of wind gust thresholds in Meteoalarm, ECA\&D Report, $2010 \mathrm{~b}$.

WHO: Improving public health responses to extreme weather/heatwaves, EuroHEAT: Technical Summary, World Health Organization Europe, 2009.

WMO: Guide to public weather services practices, TD No. 834, 1999.

WMO: Guide on improving public understanding of and response to warnings, TD No. 1139, 2002.

WMO: Guidelines on cross-border exchange of warnings, TD No. 1179, 2003.

WMO: Proceedings of the Meeting of Experts to Develop Guidelines on Heat/Health Warning Systems, WCASP No. 63, WMOTD No. 1212, 2004.

WMO: Guidelines on integrating severe weather warnings into disaster risk management, TD No. 1292, 2005.

WMO: Comprehensive risk assessment for natural hazards, TD No. 966. Rep, 2006.

WMO: Guidelines on early warning systems and application of nowcasting and warning operations, TD No. 1559, 2010. 